\title{
Citizenship in an Enlarging Europe: Contested Strategies
}

\author{
BARBARA EINHORN* \\ School of Social Sciences and Cultural Studies, University of Sussex
}

\begin{abstract}
This article explores some of the debates surrounding the gendered impact of both the democratisation process and European Union enlargement on the countries of Central and Eastern Europe. It focuses on three key issues of gender-equitable citizenship: debates about the best mechanisms for achieving gender equality in mainstream politics; questions about the efficacy of civil society activism in relation to mainstream politics; and the pros and cons of gender mainstreaming as a key component of EU enlargement. It also raises the question of the most appropriate frame for achieving more gender-equitable societies: the nation-state or supra-national institutions such as the European Union.
\end{abstract}

Sociologický časopis/Czech Sociological Review, 2005, Vol. 41, No. 6: 1023-1039

\section{Introduction}

This article is concerned with the opportunities for and constraints on the achievement of gender-equitable societies in Central and Eastern Europe. ${ }^{1}$

It focuses on three debates, all of which illustrate the complexity of the issues at stake, the varying pace and scope of change, and some of the factors influencing these changes. The three areas of debate are:

- mechanisms for increasing female political participation and introducing gender-sensitive policies in mainstream politics;

- contestations about the role and efficacy of civil society activism in relation to mainstream politics;

- pros and cons of gender mainstreaming as the EU-favoured strategy for the achievement of gender-equitable outcomes.

\footnotetext{
* Direct all correspondence to: Barbara Einhorn, Director of Graduate Studies, School of Social Sciences and Cultural Studies, University of Sussex, Falmer, East Sussex, BN1 9SJ, UK, e-mail: b.einhorn@sussex.ac.uk

${ }^{1}$ It goes without saying that the transformation process has differed in pace, scope and nature within individual countries in the regions. Beyond individual country differences, the trends evident over the past more than fifteen years vary within the region. Thus there are both notable inter-country differences and contrasting directions of development between the sub-regions of East Central Europe, Eastern and South-Eastern Europe, and Central Asia. The process of EU enlargement is contributing to widening the gaps between these regions in terms of political participation.
}

(C) Sociologický ústav AV ČR, Praha 2005 
The first two issues represent the age-old feminist - and wider activist - debate about the relative effectiveness of top-down versus bottom-up strategies for increasing gender equality. Will increasing the level of gender equality in legislatures, i.e. increasing the number of female politicians, necessarily achieve a shift in legislation and policy towards more gender-sensitivity? Advocates of this approach argue that there is a need for a 'critical mass' or 'threshold level' of female political representatives in national and local legislatures, and tend to favour quotas as a form of positive discrimination likely to achieve such a 'critical mass' [Lovenduski, 2001]. Opponents are sceptical about the possibility of achieving significant change through mainstream political means and argue rather for the efficacy of grassroots activism 'from below'. This view has been given a very substantial boost in Central and Eastern Europe since the fall of the state socialist regimes, both by governmental and non-governmental, national and international donor agencies, all of whom have lauded civil society activism as the single most important ingredient in the democratisation process.

Both these strategies are relevant mainly at the national level. Another approach is the policy of gender mainstreaming, adopted by the United Nations at the 1995 Beijing World Conference on Women and very much favoured by the European Union. Gender mainstreaming is highly relevant to discussions and developments within the region of Central and Eastern Europe, since it - at least formally - formed part of the negotiations and preparations for the 2004 accession to the EU of the first eight countries from the region. This third approach to increasing gender equity in turn raises questions as to what is the most appropriate frame for addressing equalities issues: the nation-state or supra-national bodies such as the European Union. This article therefore discusses the three strategies for gender equity described above and also raises questions about the most relevant framework for achieving them.

The transformation process in Central and Eastern Europe to date has been undertaken - as have political restructuring processes in Western European 'old' EU member states - under the aegis of an assumed consensus around the neo-liberal market model. This version of the 'convergence theory' is the result of a transition from a bi-polar to a uni-polar world dominated by the processes of economic globalisation on the one hand, and US-led neo-liberal rhetoric affecting politics, economics and social policy on the other. In Central and Eastern Europe it marks the policy outcome of the political abandonment of the socialist rhetoric of egalitarianism and social justice in favour of the liberal discourse of individual liberty and (economic) opportunity.

The fundamental nature of the transformation in Central and Eastern Europe has resulted in profound social, economic and political dislocations. The relative withdrawal of the state from welfare provision within the externally imposed neoliberal paradigm has exacerbated the impact of economic restructuring [Steinhilber 2002]. Some of the negative effects have been huge increases in poverty and a widening income gap [Daskalova 2000: 339]. Some authors would claim that one of 
the most definitive effects has been the re-emergence of class as a social determinant in the region [Gapova 2002; Regulska 2002]. Economic losses are presented as more than matched by new opportunities, both in terms of entrepreneurship and the freedom (not always matched by the capability) to organise politically. Yet in several countries the increased space for individuation and the establishment of differentiated identities has encouraged discrimination, marginalisation and - in extreme cases - conflict based on ethnic or religious 'otherness'.

Clearly there have been differences in the approach and implementation of the neo-liberal paradigm. Silke Steinhilber contrasts Poland's radical economic transformation strategy with the Czech Republic's 'mix of neoliberal and social democratic elements of reform' [Steinhilber 2005: 1]. In social policy terms, this is reflected in the tension between a tradition of - and in some countries continued commitment to - extensive welfare provisioning and substantive income redistribution through the state on the one hand, and the residualist social policy set-up advocated by the currently dominant global neoliberal economic framework on the other' [ibid.]. Nonetheless, the currently dominant influence of IMF/World Bank neo-conservative ideology - together with the pressures of EU accession - have led to a level of 'real' convergence between Eastern and Western Europe which could facilitate the acknowledgement of common issues among feminist scholars across Europe.

The discourse of transformation has highlighted gains in civil and political rights, while the process itself has been, in material terms, almost entirely focused on economic restructuring: marketisation, interpreted as privatisation. Thus European Union accession, while embodying hopes in relation to the EU commitment to gender equality through gender mainstreaming, is in practice a process of economic alignment and integration. In this process, concerns not only for gender equality, but also for citizenship and social justice are marginalised. The political is seen as secondary to the economic, and hence issues of gender justice, always an add-on to central EU concerns about the labour market, are pushed aside [Jezerska 2003: 172]. Indeed, in the aftermath of the 'no' votes in Holland and France in 2005, there was talk of a retreat from a politically united Europe and a return to the minimalist free trade association the European Economic Community originally represented. This scenario would constitute a further threat to concerns for gender equality - in terms both of social justice and equitable political representation.

Uncertainty about the future of the European Union compounds existing doubts about the EU's genuine commitment to social and gender justice. Ironically, it is the concerns of France and the Netherlands about protecting their superior welfare state that in part prompted the 'no' vote. Conversely, in the UK the possibility of appealing to the European Court of Justice or the European Commission on Human Rights has been seen as giving leverage to feminist activists, who regarded this possibility of appeal to a supra-regional body as a mechanism for exerting pressure on the more conservative British nation-state to implement EU gender-equality directives. In Britain, the beginning of the Thatcher government in 1979 had signalled 
the end of the consensus over the post-World War II welfare state based on universal entitlements, and the end therefore also of assumptions about citizenship being based on political, economic and social rights, as developed by T.H. Marshall.

\section{Strategies for gender-equitable citizenship}

Regardless of their adherence to particular versions of feminist theory, feminists East, West, North and South have long debated the optimal strategies for the achievement of more gender-equitable citizenship. There is disagreement about whether an increased level of female political participation is indeed a sufficient or even necessary condition for achieving that end [Lepinard 2005]. Two particular strategies that are currently on the international agenda but whose merits are contested are: quotas as a means towards the end of more gender-equitable political representation, and gender mainstreaming as a government policy designed to achieve gender equality One could argue that these contestations are symptomatic of the old debates concerning the merits of top-down versus bottom-up approaches. ${ }^{2}$ They also symbolise the difference between gender-neutral approaches to equality of opportunity and gender-specific positive action designed to overcome the legacy of culturally reinforced social hierarchies of gender inequality. Since the Fourth UN World Conference on Women in Beijing in 1995, international agencies and supra-national bodies such as the European Union have favoured gender-mainstreaming strategies. In many regions of the world, and also in the context of EU enlargement, this strategy is hampered by the lack of women in legislatures, and by the fact that women's rights or gender equality as a goal are, with few exceptions, not political party priorities, and that as a consequence, political parties do little to foster higher levels of gender equity in political representation. ${ }^{3}$ During the run-up to EU accession the Polish Centre for Women's Rights reported as late as 2000 that 'Poland has done nothing to adjust its legislation to EU standards in the field of equal status of women and men and that issue is probably the last item on the government priorities list' [Women's Rights Centre 2000: 14; cited in Regulska 2002].

The suspicion of top-down statist approaches that was prevalent in the early years of transformation has persisted in some countries and goes some way to explain the enhanced status of NGO activity in the region as opposed to mainstream political involvement. This suspicion was a perfectly understandable reaction to the

\footnotetext{
${ }^{2}$ Some might maintain that both of these strategies represent top-down mechanisms; however, it could be argued that quotas are a mechanism introduced as a result of women's movement lobbying. The basis for such lobbying has been that whilst numerically increased levels of female representation do not guarantee the introduction of gender-sensitive legislation or the implementation of gender-equitable policies, achieving a 'critical mass' of women is a precondition for this to occur, since marginalised 'token' women have no possibility of altering the prevailing gendered hierarchies of power.

3 See Lovenduski [2001: 743, 745, 752] on this in relation to the UK elections of 2001.
} 
experience of an all-powerful and invasive state during the socialist period [Szalai 1990]. Nor is anti-statism peculiar to East European feminisms [Mansbridge 2003]. However, when Western or Southern feminists ponder whether or not to 'give up on the state' they are (with the exception perhaps of Latin American countries re-establishing democratic institutions after the end of military dictatorships) not speaking from a position of experiences of the state similar to those in Central and Eastern Europe. The resistance to state-led solutions has - until recently - expressed itself, among other ways, in the rejection of the use of quotas as a political strategy. To many feminists from the region quotas seem to smack of the undemocratic manipulation of the political process by the previous regimes through the installation of puppet 'representatives' in parliaments, whose job it was merely to rubber-stamp decisions taken elsewhere, i.e. in the Central Committees and Politburos of the ruling Communist Parties (with women notably absent from those higher echelons of political power) [Einhorn 1993; Jezerska 2003: 171].

However, the experience of dramatic declines in the levels of female political representation in the early democratic elections in several countries in the region eventually led to shifts in this attitude. ${ }^{4}$ Women activists in Georgia, Latvia, and Poland, for example, now advocate the adoption of quotas for women as a necessary short-term strategy for achieving some degree of 'critical mass' of women in parliaments and legislatures, and thus as a mechanism for the achievement of gender equality. In Poland, strong lobbying by the Parliamentary Women's Lobby and the adoption by three political parties of a 30\% quota rule led to an increase in the percentage of women, from 13\% in 1997 to 20\% in 2001 in the Sejm (Lower House), and from $12 \%$ to $23 \%$ in the same period in the Senate (Upper House) [Fuszara 2000; Spurek 2002]. Drude Dahlerup and Lenita Freidenvall [2005] point out that quotas are not the only, or even necessarily the optimal, route to equal representation for women. The doubling of the share of seats held by women in the Westminster Parliament in 1997 from 9\% to 18.9\% [Lovenduski 2001: 744] illustrates Dahlerup and Freidenvall's argument that 'major historical leaps in women's parliamentary representation can occur without quota provisions, just as the mere introduction of quo-

\footnotetext{
4 Women's political representation fell drastically in the first democratic elections from an average $33 \%$ to levels of $10 \%$ and below. Even more alarmingly (given the token nature of representation during the state socialist period), the level fell further in several countries in subsequent democratic elections. Thus in Albania, for example, women held $36 \%$ of parliamentary seats prior to 1989 . Their share fell to $20 \%$ in 1991, but, much more drastically, to $7 \%$ in the 1997 elections. There appears to be an East-East divide opening up, with Central European countries showing improvements in levels of female political participation in subsequent elections, while levels in Eastern and South-Eastern Europe and the Central Asian republics continue to fall. However, in several countries where there has been improvement, it is only slight. In Ukraine, women held $4.2 \%$ of parliamentary seats in 1994, and 5.6\% in 1998 . In Hungary, the level rose from 7\% in 1990 to 8.5\% in 1998 [NWP/OSI 2002: 11; UNICEF 1999]; in several cases, what has happened is that the East European level has fallen to a level comparable with Western European countries).
} 
tas has not resulted in uniform increases in the number of women parliamentarians worldwide' [Dahlerup and Freidenvall 2005: 27; see also Lepinard 2005]. Nevertheless, despite the complex difficulties associated with implementation, 'electoral gender quotas as an affirmative action measure to increase women's representation' have been adopted now in about forty countries worldwide as a first step towards equality in political representation [ibid: 26-7].

The introduction of quotas can improve gender equity at the national level. Another reason for not abandoning the nation-state, and one particularly pertinent in the case of Central and Eastern Europe, is the loss of social entitlements which followed the transformation process [Daskalova 2000: 346-7]. During a 1995 political debate in Hungary, the proposal to dismantle remaining universal social welfare entitlements was justified by arguments that 'social expenditures have to be brought down to secure a "healthy" economy, while welfare universalism had to be abolished to ensure economic "growth"' [Haney 2002: 186]. The relative losses women have experienced in access to the labour market have been well documented [Einhorn 1993, 1997; Lokar 2000]; so too have the issues of discriminatory hiring practices and sexual harassment that followed [Daskalova 2000: 340, 342; Einhorn 1997; Haney, 2002; Lokar 2000; NWP/OSI 2002; True 2003b].

The neo-liberal market paradigm empowers the male economic actor as the citizen with the capacity to exchange contracts in the marketplace. Without social entitlements, for example, the entitlement to adequate and affordable childcare in a context where women are still seen as primarily responsible for looking after children, women do not have an equal capacity to access the public spheres of either the market or the polity. This situation is exacerbated by the nationalist and religious discourses paramount in several countries of the region that allot women sole responsibility for the private sphere and enjoin them to produce babies for the nation [Daskalova 2000: 350; Gapova 1998; Slapsak 1997; Zhurzhenko 2001b], discourses that insidiously both reinforce the economy's need to shed labour and legitimise the closure of childcare facilities.

In these contexts, it is necessary to rethink the optimal modality for the achievement of gender-equitable outcomes, particularly in relation to the question of women's full participation as active political subjects in determining policies and practices that affect their lives. A theory of social entitlements rather than one of individual rights best enables the necessary conceptual and practical linkages between state, market, and household [Einhorn 1995, 2000a, 2006]. It is necessary to reiterate here that the state, historically the provider of welfare, guarantor of social entitlements, and the actor with regulatory power over working conditions, has a crucial role to play in enabling women to develop the capacity to access both market and polity on an equal basis with men. Obviously the nation-state's power to enforce decent working conditions is waning in the face of powerful transnational corporations. In future, therefore, there will be a need to develop transnational regulatory bodies for the protection of citizens' and workers' rights. However, for the short- to medium-term, in the absence of easily recognisable or accessible bodies of 
this kind, political participation at the nation-state level will remain important. The extent to which the regulatory role in relation to issues of social justice and gender equality hitherto played by the nation-state is increasingly taken on by supra-national legislative and enforcement bodies such as the European Parliament or the European Court of Justice is a development to be watched.

\section{The nation-state and political representation}

The mutual influence and the two-way effects - in the East and the West - of European Union enlargement have repercussions for two issues to be discussed in this section. Both issues concern contestations around the appropriate analytical framework for dealing with the impact of political transformation in Central and Eastern Europe. The first question is whether the relevant frame for rights claims in the era of EU enlargement (and in the wider context of globalisation) is the nation-state or supra-national institutions. The second is the role of what is variously referred to as a 'critical mass', or a 'threshold level' of women in legislative bodies, or in other words a minority large enough to facilitate the effective consideration of women's interests and women's perspectives [Lovenduski 2001: 744; 746; Rai 2003: 38]. ${ }^{5}$

Nancy Fraser argues that today, 'the Keynesian-Westphalian frame is losing its aura of self-evidence' [Fraser 2005: 2]. For her, this loss of self-evidence denotes the demise of Western European social democratic welfare states as a result of neo-liberal policies, and simultaneous challenges to the nation state as the unquestioned address for citizenship claims as a result of supra-national institutions of governance such as the EU and the UN, but also, more powerfully still, of the growing impact of economic globalisation. Therefore, she asserts that in the post-social democratic era 'it is no longer axiomatic that the modern territorial state is the appropriate unit for thinking about issues of justice, nor that the citizens of such states are the pertinent subjects' [Fraser 2005: 3]. Fraser argues that greater social justice can be achieved through transnational solidarity, backed up by supra-national institutions of governance that are in a position to mediate between local (or national) claims and the forces of economic globalisation. This is a very attractive proposition, and some evidence of it exists already in the form of the very effective transnational networking among NGOs that has emerged since the 1995 UN Conference on Women in Beijing. Nevertheless, the jury is still out on whether the nation-state has been superseded by regional or international institutions in terms of its ability to confer citizenship rights or implement human rights. It is still indisputably the nation-state, for example, that has the power of inclusion and exclusion, particularly in terms of permitting immigrants and refugees to gain access to nationality and hence also to citizenship rights.

\footnotetext{
${ }^{5}$ Joni Lovenduski [2001: 744] states that 'the figure set for critical mass of women is about $30 \%$ of the legislature'.
} 
In many instances the national - or in many cases the local - state remains the address for benefit claims [Szalai 2005]. The local state has the power, not merely to distribute benefits in a social welfare regime based on residual needs, rather than universal entitlements, but also to act as the arbiter of eligibility. In judging who qualifies as 'deserving' poor, local welfare officials in Hungary are, argues Julia Szalai, applying gendered and racist discourses, which have the effect of excluding mainly Roma people from full political and social rights, and hence from equal citizenship status with the majority Hungarian population.

In 2004, a special issue of the International Feminist Journal of Politics was dedicated to exploring issues of gender and governance in the era of globalisation [Waylen and Rai 2004]. In it, Shirin Rai argued persuasively that 'comparative feminist scholarship provides key insights into the constitutive, gendered nature of the state in the global political economy and thus challenges the "declining state" thesis'. She documents the 'decisive shift' in the 1990s 'from scepticism and caution towards the state to an engagement with and embrace of state institutions' on the part of feminists [Rai 2004: 584, 586]. Shirin Rai had earlier on argued that the danger of co-option of the national machineries and their 'gender agenda' by the state does not negate 'the importance of the state as an arena for furthering gender justice' [Rai 2003: 19]. Of particular relevance to this article is the centrality of women's movement efforts to change state policy, both through arguing for quotas for women in state legislatures, and through engagement with the national machineries for gender mainstreaming.

Discussing the relevance of the nation-state to gender equality aspirations in Central and Eastern Europe, Joanna Regulska [2002: 11-12] observes that 'neither the official "sameness" imposed by the communist political culture nor the "difference" engendered by differing degrees of democratisation has liberated women as fully participating political actors'. She therefore poses the question: 'Will the fact that women have not found significant opportunities in formal, domestic political structures make them more likely to search for alternative ways to act politically beyond the nation-state?' The impressively effective international lobbying activities of Karat, a coalition of NGOs in Eastern Europe, might suggest an affirmative response. Yet as already argued, such transnational networking, however effective in lobbying supra-national bodies such as the EU or the UN, in the short- to mediumterm must be seen as complementing rather than supplanting the nation-state's role as the appropriate address for citizenship claims.

Whilst it is true that the existence of the European Court of Human Rights has enabled some individuals within the EU to take their own governments to court, this is costly and difficult, and surely represents the exception. This possible route for remedying gender injustice is an example of negative freedom, in the tradition of 18th-century liberal democratic theory. It also exemplifies the way that human rights discourse - and indeed liberal democratic discourse - focuses on the individual, rather than on social groups, whereas gender equality - despite the multiple differences and inequalities between women fostered in the neo-liberal market model 
[Szalai 2005] implies the need to overcome structural disadvantage, and not mere individual difficulty. Most women in Western Europe - whether they are exercised about the continuing gender pay gap, the glass ceiling, occupational segregation in all its forms, parental leave, domestic violence, lesbian rights, or the rights of female migrants and asylum seekers - possess neither the social nor the financial capital to access such supra-national institutions. For the majority then, the nation-state remains the only institution to which they realistically have access and can address their claims for citizenship rights, social entitlements, and greater social justice.

\section{Civil society activism as political strategy}

Most feminist scholars stress the necessity for both increased levels of female political representation, and pressure from below in order to make gender-mainstreaming strategies effective [Hoskyns 1996; Rai 2003; Stratigaki 2005]. The transformation process has seen a veritable explosion of 'civil society' activity in Central and Eastern Europe, at the same time as the role of civil society associations and NGOs has become the focus of funding and policy-making by international donor agencies and governments alike. Political theory has long established that women - and not only those adopting the anti-state stance specific to this region in the post-communist period - find grassroots and local, single-issue as opposed to mainstream political party involvement to be more in tune with and compatible with their commitments and lifestyle. An enormous number of NGOs has emerged in the region, many of them initiated and managed by women. However, in the particular context of a rigidly applied neo-liberal market model and the loss of social provision this entails, such political involvement takes on particular meanings, constitutes particular political subject positions, and is accompanied by particular risks [Einhorn and Sever 2003].

Specifically, there is a danger of what has been referred to as the civil society 'trap' [Einhorn 2000a; 2006; Einhorn and Sever 2003]. This is where women's NGOs in effect provide some of the welfare functions abandoned by the state. Karat, an advocacy coalition of women's NGOs in the region formed following the 1995 Beijing UN conference, maintains that women are active in NGOs on an equal basis with men, and that NGOs have been successful in influencing government policy in several countries. However, they also document the lack of capacity-building and expertise, the dependence on foreign donors, and the distortions this can produce in NGO priorities and activities [Barendt 2002; Karat 2002]. Karat recognises the need for NGO advocacy work to be professionalised; Sabine Lang argues in contrast that the 'NGOisation of feminism' dilutes its political and dynamic impact [Lang 1997]. In my view, state retrenchment reduces NGOs and other civil society organisations to acting as service providers, rather than as political activists and social advocates.

The theory of a civil society 'trap' [Einhorn 2000a; 2006] relates to the ways in which it is women's unpaid labour - often performed by women who have been made 
redundant and have difficulty finding re-employment - that provides social supports such as childcare or care of the elderly. This labour remains invisible, simultaneously depended upon yet unrecognised by state agencies. Women's NGOs and grassroots activist groups are filling the vacuum where the state has withdrawn from public service provision. This 'trap' at least in part derives from the idealisation of civil society that followed the fall of state socialism. Civil society was seen as the epitome of the democratic space that had earlier been lacking, both by dissident activists and theorists within the region, and by Western analysts and international donor agencies.

There are debates surrounding the conceptualisation of civil society and its relationship to autonomous women's or feminist movements. In the context of the transformation process in Central and Eastern Europe, Ferenc Misslivetz, a Hungarian academic and former dissident activist once commented: 'We dreamed of civil society. What we got were NGOs.' But it could be argued that in order to overcome the donor dependency and potential loss of political edge faced by NGOs in the region, and thus to avoid the civil society 'trap', the imbalance between the market and the state needs to be overcome. While regional resistance to statist solutions is perfectly understandable, given the recent history of all-controlling state socialist regimes, Western and Southern critics of the Washington Consensus see the neoliberal paradigm as having seriously under-estimated the necessary and constructive place of the government regulation in economic development, not to mention its role in the quest for social justice.

Compounding the civil society 'trap' is the civil society 'gap' [Einhorn 2000; 2006; Einhorn and Sever 2003]. This relates to the lack of channels of communication between NGOs and social movements on the one hand and political power structures and state agencies on the other. How does civil society activism by women translate into gender-sensitive policymaking? Both the Beijing Platform for Action and subsequent recommendations have stressed the 'need for greater consultation between NGOs and national machineries' [Rai 2003: 35]. Shirin Rai argues that, in this context, 'the question of access to government becomes crucial' [ibid].

Karat Coalition has identified two problems in Central and Eastern Europe which precisely exemplify this 'gap': 'Despite the fact that a process of opening the state authorities to the public has started, NGOs are kept outside mainstream policy formation. ...The main obstacle is the unresponsiveness and unwillingness of the administration to engage in a dialogue with civil society or even with other departments and governmental institutions' [Karat 2002]. Thus there are risks in focusing on bottom-up strategies, or grassroots activism, to the exclusion of involvement in conventional party politics and the policies of gender mainstreaming. The only way to ensure there is effective transmission of views from civil society to government, and efficient translation of grassroots insights and demands into new legislation and state policy, is to institute mechanisms for regular two-way communication. Overcoming the civil society 'gap' also requires some level of commitment on the part of national governments to take seriously - to the point of adopting and institutionalising - some of the measures proposed by civil society organisations. 


\section{The EU and gender mainstreaming}

The threat posed by the European Union's exclusive focus on the economic sphere has already been alluded to above. This may simply elide many of the most crucial problems of political participation and social entitlements faced by women in Central and Eastern Europe. Speaking at a conference in 2002 on behalf of the Karat Coalition of women's NGOs from the region, Regina Barendt stated: 'If state intervention remains limited to the labour market, as was the case under socialism, the most immediate impact is to intensify the exploitation of women on the one hand, and fail to alter the traditional gendered division of labour on the other. We in the region have known this for 25 years, but it is only now slowly gaining recognition in the EU' [Barendt 2002]. The dangers for gender equality inherent in the way that in the EU 'from the beginning the social has been subsumed within the economic and only given a separate focus when this appeared functional or necessary to economic integration' were identified earlier by Catherine Hoskyns [1996: 207], but have not necessarily been adequately addressed since then within EU policy.

Joanna Regulska [2002] has maintained that 'the increasing privileging of economic over social and political ties has further threatened CEE countries' hopes for joining the EU as equal partners'. She found that the evidence from the negotiations around accession 'reinforces the impression that there is a lack of EU commitment to carry gender discourse as a part of accession negotiations'. Furthermore, she felt that while the Polish government had felt obliged, admittedly only in May 2001, to introduce 'required legislation regarding equal pay and equal treatment of men and women', this was confined to measures in the sphere of the labour market, and 'purely instrumental' [Regulska 2002]. Jacqui True documents the Czech 'government's failure to properly implement' the equal opportunities legislation it introduced as an amendment to the Labour Law in 1999 for the purposes of harmonisation with EU requirements [True 2003b: 98-100]. On this evidence, it would seem that neither national governments in the region nor the EU itself have treated gender as a measure of readiness for accession. In the run-up to the first round of enlargement, it seemed that compliance or non-compliance with the gender norms of EU legislation was likely neither to impede nor to delay accession for those countries that joined in 2004 [Steinhilber 2002].

The EU policy of gender mainstreaming itself hides a lack of conceptual clarity in terms of meaning, intentionality and purpose. ${ }^{6}$ Is the goal, for example, equal treatment, equality of opportunity, or equality of outcomes? Does it necessitate equal opportunity legislation or anti-discrimination legislation? In political terms, does it involve gender-neutral, positive discrimination, or positive action poli-

\footnotetext{
${ }^{6}$ Maria Stratigaki [2005: 167] notes that "both "gender" and "mainstreaming" are conceptual terms that have evoked more confusion, misunderstanding and questions than any other terms used in EU equality policies. Until 1996, there was no clear definition in European Community documents for the term "gender mainstreaming"'.
} 
cies [Lovenduski 2001] ? ${ }^{7}$ Is there a problem in the fact that gender mainstreaming is a top-down strategy? Might a crucial political edge in terms of feminist goals of social transformation be lost through this strategy [Rai 2003: 19]? 'Gender mainstreaming should not replace politics' [Verloo 2002]; nor should it be used to mask issues of women's rights, to withdraw funding from - or eliminate - measures of positive discrimination for women.

Maria Stratigaki describes, from her eight-year experience of working in the Equal Opportunities Unit of the European Commission, the conflict during the development of gender mainstreaming between two different policy frames. One frame emphasises the transformative potential of GM in 'complementing and reinforcing positive action and equality legislation'. The other uses GM 'as an alternative to positive action', which can be 'used to downplay the final overall objective of gender equality' [Stratigaki 2005: 165-66, 168]. As Stratigaki asserts, 'without simultaneously tackling the accumulated inequalities between the sexes and reinforcing gender-specific policies, GM effectiveness cannot be assured' [ibid: 169].

In practice, gender mainstreaming strategies, especially within the European Union context, are often formulated in terms of economic efficiency, thus as effective strategies for integrating women into the labour market, rather than within a framework of political transformation towards the goal of gender-equitable societies. Stratigaki claims [2005: 176, 180] that there is evidence of 'cooptation by economic priorities' and that 'the use of GM to eliminate positive action can be found in EU labour market policy texts' (see also Rai [2003: 29]). Gender mainstreaming also highlights the ongoing dilemma around equal treatment versus special treatment. The disputes in Britain leading to the rejection of affirmative action measures in favour of positive action illustrate this dilemma very clearly (see note 7 below).

Added to the lack of conceptual clarity at the heart of the EU is the fact that gender mainstreaming machinery in the accession countries remains systemically weak. Zuzana Jezerska [2003: 167] points to the lack of definitional clarity, as a result of which 'national machinery for women' can take a wide range of institution-

\footnotetext{
7 While positive discrimination permits enhancing the number of women candidates for political office through women-only shortlists, quotas, or placing women top on party lists, positive action allows only the encouragement of women to put themselves forward for office, but no measures which could be seen as going against gender-neutral equal opportunity legislation. An example was the introduction in 1996 of women-only short lists for political candidacy in the UK, which was overturned by an industrial tribunal on the grounds that it contravened the UK's Sex Discrimination legislation. Interestingly, Maria Stratigaki [2005] uses the term 'positive action' in contrast to equality-based gender mainstreaming approaches. Joni Lovenduski [2001: 751] describes how the equal opportunities approach in the Westminster electoral system - 'the change from positive discrimination (mandatory quotas of women) to positive action (voluntary quotas of women candidates' - led to a fall in the number of female MPs between the 1997 and 2001 elections. In terms of difference-based, genderspecific policies, I would therefore argue that 'positive action' constitutes a diluted and much weaker form of action than 'positive discrimination'.
} 
al forms, 'from NGO status to a very strong mandate within the government'. In Poland, the Equal Opportunities Officer appointed in November 2001 did not have an automatic right to attend cabinet meetings, nor to insist that her recommendations be translated into legislation or government policy. Initial attempts by the Parliamentary Women's Lobby to introduce a draft Equal Opportunities Bill into the Polish Sejm, for example, met with laughter and ridicule. As of 2002, the only country in Central and Eastern Europe that had an ombudsperson dealing with gender issues was Lithuania, which in June 2002 introduced amendments to its 1998 Equal Opportunities legislation allowing a resort to 'positive discrimination' in order to ensure women's rights [NWP/OSI 2002: 14].

Such weaknesses in the machinery designed to institutionalise gender-mainstreaming policies are replicated in many of the pre-2004 EU member states. In the UK, for example, the first fully paid Minister for Women was appointed as late as 2001 [Lovenduski 2001]. However, there has as yet been little sign of effective gender mainstreaming policies emanating from this office and adopted by the government. Few countries acknowledge the need - as Germany does - for state institutions to institute a dual strategy, combining gender-mainstreaming policies with positive measures to enhance gender equality. Even there, however, gender-mainstreaming activities have been starved of resources both in terms of finances and personnel.

It is obvious, therefore, that even where the formal mechanisms and legislation are in place, there are questions about the level of implementation. As in Western Europe, many of the countries in Central and Eastern Europe lack sufficient numbers of women in positions of power in legislatures and in trade unions who are committed to gender equality and could ensure that legislation, once passed, or EU gender-related directives, become translated into reality. Furthermore, it is clear that the implementation of gender mainstreaming policies and the effectiveness of national women's machineries depend in large part on the existence of 'strong democratic movements holding these bodies accountable' [Rai 2003: 19], or in other words on 'the dynamic involvement of political, social and civil actors with high visibility' [Stratigaki 2005: 172]. It is therefore important to consider the fact that women's mainstream political participation on the one hand, and civil society activism and lobbying on the other, are intimately related.

\section{Conclusion}

In conclusion, it is argued that there is a need for both top-down gender mainstreaming policies and for grassroots campaigning pressure on the part of strong women's and feminist movements [Einhorn 2000; 2006; Hoskyns 1996; Jezerska 2003; Rai 2003; Stratigaki 2005]. Jacqui True and Michael Mintrom validate the key role of social movements and particularly the transnational feminist movement in 'the diffusion of gender-mainstreaming mechanisms' [True and Mintrom 2001: 27]. 
In her later study of the efficacy and transformative potential of gender mainstreaming as a strategy, True concludes that 'gender mainstreaming is an open-ended and potentially transforming project that depends on what feminist scholars, activists and policy-makers collectively make of it' [True 2003a: 368].

Without support from mainstream politicians and the institution of properly supported mechanisms for their implementation, gender-mainstreaming policies cannot succeed. Shirin Rai documents 'the paucity of resources available to national machineries in most countries' as an inhibiting factor [Rai 2003: 35]. As several analysts point out, the key to success in terms of the resourcing which can enable full implementation of gender mainstreaming strategies is political support at the highest levels [Rai 2003: 34, 37]. Yet Zuzana Jezerska feels that 'what is lacking most is political will' in Central and Eastern European countries, and that this explains 'the rather patchy growth of women's national machineries' in the region [Jezerska 2003: 182].

Political will also needs to be generated and maintained. Only pressure from below can ensure that issues of gender equity are kept on the agenda of national, supra-national and international institutions, and that gender-sensitive policies are not merely written into legislation, but are also given weight in terms of the human and financial resources necessary for their implementation. Shirin Rai stresses that whilst national machineries have an 'agenda-setting role', 'their legitimacy derives from the close contact they are able to maintain with women's groups' [Rai 2003: 25]. Both political will and grassroots activism are therefore necessary but not sufficient preconditions for the achievement of gender equality. Beyond this combination, the crucial catalysts for effectiveness are communication and influence in both directions. In other words, keeping the channels open for the transmission of grassroots demands to the politicians, and exerting influence to ensure their passage into legislation, are crucial if policies such as gender mainstreaming or quotas are to make a real difference, not only to women's lives, but to the life and health of societies as a whole, both nationally and internationally.

BARBARA EINHORN is reader in Gender Studies and director of Graduate Studies in the School of Social Sciences and Cultural Studies at the University of Sussex, UK. She is also Associate Editor of the 'European Journal of Women's Studies' and a member of the editorial board of the International Feminist Journal of Politics and the Asian Journal of Women's Studies. She has acted as a consultant on gender to the United Nation's Women's Programme (UNIFEM), to the International Labour Organisation (ILO) and to the World Bank. Her research focuses on citizenship, civil society and gender politics, with special reference to the transformation process in Central and Eastern Europe; identity, 'home' and belonging, especially in relation to (multiple) migration; and issues of nation, gender and nationalism. 


\section{References}

Barendt, Regina. 2002. “Women for Europe and Europe for Women: KARAT Coalition Lobby-Building, Network Creation, Building Alliances and Gaining Power." Paper presented to the conference Europe's Daughters: The Traditions, Expectations, and Strategies of European Women's Movements, Berlin, June.

Bulgarian Gender Research Foundation. 2003. "Gender Assessment of the Impact of EU Accession on the Status of Women in the Labour Market in CEE." Sofia: BGRF (accessed via www.KARAT.org).

Dahlerup, Drude and Lenita Freidenwall. 2005. “Quotas as 'Fast Track' to Equal Representation for Women: Why Scandinavia is No Longer the Model." International Feminist Journal of Politics 7(1): 26-48.

Daskalova, Krassimira. 2000. "Women's Problems, Women's Discourses in Bulgaria." Pp. 337-369 in Reproducing Gender: Politics, Public, and Everyday Life after Socialism, edited by Susan Gal and Gail Kligman. Princeton, NJ: Princeton University Press.

Einhorn, Barbara. 2006. Citizenship in a Uniting Europe: From Dream to Awakening. London and New York: Palgrave Macmillan.

Einhorn, Barbara. 2000. "Gender and Citizenship in the Context of Democratisation and Economic Reform in East Central Europe." Pp. 103-124 in International Perspectives on Gender and Democratisation, edited by Shirin M. Rai. Basingstoke and London: Macmillan.

Einhorn, Barbara. 1997. “The Impact of the Transition from Centrally Planned to MarketBased Economies on Women's Employment in East Central Europe." Pp. 59-84 in Promoting Gender Equality at Work, edited by Eugenia Date-Bah. London: Zed Press and International Labour Organisation.

Einhorn, Barbara. 1995. "Ironies of History: Citizenship Issues in the New Market Economies of East Central Europe." Pp. 217-233 in Women and Market Societies: Crisis and Opportunity, edited by Barbara Einhorn and Eileen Janes Yeo. Aldershot, UK and Brookfield, US: Edward Elgar.

Einhorn, Barbara. 1993. Cinderella Goes to Market: Gender, Citizenship, and Women's Movements in East Central Europe. London and New York: Verso.

Einhorn, Barbara and Charlotte Sever. 2003. "Gender and Civil Society in Central and Eastern Europe." International Feminist Journal of Politics 5 (2): 163-190.

Fraser, Nancy. 2005. "Democratic Justice in a Globalizing Age: Thematizing the Problem of the Frame." Paper presented to a Symposium at the University of Sussex, 7 March 2005.

Fuszara, Malgorzata. 2000. “New Gender Relations in Poland in the 1990s.” Pp. 259-285 in Reproducing Gender: Politics, Publics and Everyday Life after Socialism, edited by S. Gal and G. Kligman. (2000b) Princeton: Princeton University Press.

Gapova, Elena. 2001. "Understanding the Other: A Response to Tiffany Petros' Article." Central Europe Review 3 (2); www.ce-review.org; accessed from Women's/Gender Studies Association of Countries in Transition Electronic Library.

Gapova, Elena. 2002. “On Nation, Gender, and Class Formation in Belarus ... and Elsewhere in the Post-Soviet World." Nationalities Papers 30 (4): 639-662.

Gapova, Elena. 1998. "Women in the National Discourse in Belarus." European Journal of Women's Studies 5 (3-4): 477-488.

Haney, Lynne. 2002. Inventing the Needy: Gender and the Politics of Welfare in Hungary. Berkeley, Los Angeles, London: University of California Press.

Hoskyns, Catherine. 1996. Integrating Gender: Women, Law and Politics in the European Union. London and New York: Verso.

Jezerska, Zuzana. 2003. “Gender Awareness and the National Machineries in the Countries 
of Central and Eastern Europe." Pp. 167-183 in Mainstreaming Gender, Democratizing the State: Institutional Mechanisms for the Advancement of Women, edited by Shirin M. Rai.

Manchester and New York: Manchester University Press (for and on behalf of the UN).

Karat. 2002. NGO Advocacy - Advocacy NGOs. Summary of conclusions from a report on women's and feminist NGOs in Albania, Bulgaria, Croatia and Romania.

Lang, Sabine. 1997. "The NGOization of Feminism." Pp. 101-120 in Transitions, Environments, Translations: Feminisms in International Politics, edited by Joan Scott, Cora Kaplan and Debra Keates. London and New York: Macmillan.

Lepinard, Eleonore. 2005. “Ambivalent Categories and problematic Outcomes of Gender Quotas: The Struggle over the Definition of Gender Equality in the French Parity Debate." Paper presented to the final conference of the Network for European Women's Rights (NEWR), University of Birmingham, 30 June-1 July 2005.

Lovenduski, Joni. 2001. "Women and Politics: Minority Representation or Critical Mass?" Parliamentary Affairs 54: 743-758.

Mansbridge, Jane. 2003. "Anti-Statism and Difference Feminism in International Social Movements." International Feminist Journal of Politics 5 (3): 355-360.

(NWP/OSI) Network Women's Program, Open Society Institute. 2002. Bending the Bow: Targeting Women's Human Rights and Opportunities. New York: Open Society Institute. Open Society Institute. 2002. Monitoring the EU Accession Process: Equal Opportunities for Women and Men in Poland.

Rai, Shirin M. 2004. "Gendering Global Governance." International Feminist Journal of Politics 6 (4): 579-602.

Rai, Shirin M. 2003. "Institutional Mechanisms for the Advancement of Women: Mainstreaming Gender, Democratizing the State." Pp. 15-39 in Mainstreaming Gender, Democratizing the State: Institutional Mechanisms for the Advancement of Women, edited by Shirin M. Rai. Manchester and New York: Manchester University Press (for and on behalf of the UN).

Regulska, Joanna. 2002. “Women's Agency and Supranational Political Spaces: The European Union and Eastern Enlargement." Paper presented at the Annual Meeting of the American Association of Geographers, Los Angeles, 20-24 March 2002.

Slapsak, Svetlana. 1997. "Nationalist and Women's Discourses in Post-Yugoslavia." Pp. 72-78 in Transitions, Environments, Translations: Feminisms in International Politics, edited by Joan W. Scott, Cora Kaplan, and Debra Keates. New York and London: MacMillan.

Spurek, Sylwia. 2002. Women, Parties, Elections. Lodz: Women's Rights Centre Foundation. Steinhilber, Silke. 2005. "Gender and Post-Socialist Welfare States in Central Eastern Europe: Family Policy Reforms in Poland and the Czech Republic Compared." Forthcoming in Gender and Social Policy, edited by Shireen Hassim and Shahra Razavi. UNRISD/Geneva and London: Palgrave Macmillan.

Steinhilber, Silke. 2002. Women's Rights and Gender Equality in the EU Enlargement. An Opportunity for Progress. WIDE (Network Women in Development Europe) Briefing Paper, October 2002.

Stratigaki, Maria. 2005. "Gender Mainstreaming vs. Positive Action: An Ongoing Conflict in EU Gender Equality Policy." European Journal of Women's Studies 12 (2): 165-186.

Szalai, Julia. 2005. “Cultural Diversity of Social Disintegration? 'Cultural Otherness' and Roma Rights in Contemporary Hungary." Paper presented to the conference on "Gender Equality, Cultural Diversity: European Comparisons and Lessons", London, 27-28 May 2005.

Szalai, Julia et al. 1990. "Social Policy and Socialism: Citizenship, the Working Class, Women and Welfare." Pp. 34-35 in Social Policy in the New Eastern Europe: What Future for Socialist Welfare?, edited by Bob Deacon and Julia Szalai. Aldershot: Avebury. 
True, Jacqui. 2003a. "Mainstreaming Gender in Global Public Policy." International Feminist Journal of Politics 5 (3): 368-396.

True, Jacqui. 2003b. Gender, Globalization and Postsocialism: the Czech Republic after Communism. New York, Chichester: Columbia University Press.

True, Jacqui and Michael Mintrom. 2001. "Transnational Networks and Policy Diffusion: The Case of Gender Mainstreaming." International Studies Quarterly 45: 27-57.

Verloo, Mieke. 2002. Keynote Address to the International Gender Mainstreaming Conference, Leipzig, 6-8 September 2002.

Waylen, Georgina and Shirin M. Rai. (eds) 2004. Special issue on “Gender, Governance and Globalization." International Feminist Journal of Politics 6 (4).

Zhurzhenko, Tatiana. 2001a. "Free Market Ideology and New Women's Identities in PostSocialist Ukraine." The European Journal of Women's Studies 8 (1): 29-49.

Zhurzhenko, Tatiana. 2001b. “(Anti)National Feminisms, Post-Soviet Gender Studies: Women's Voices of Transition and Nation-Building in Ukraine." Österreichische Osthefte 43 (4): 503-524. 